Studia Judaica 23 (2020), nr 2 (46), s. 380-389

doi:10.4467/24500100STJ.20.018.13661

Joanna Nalewajko-Kulikov (iD) https://orcid.org/0000-0002-4946-9905

\title{
Rachela Fajgenberg
}

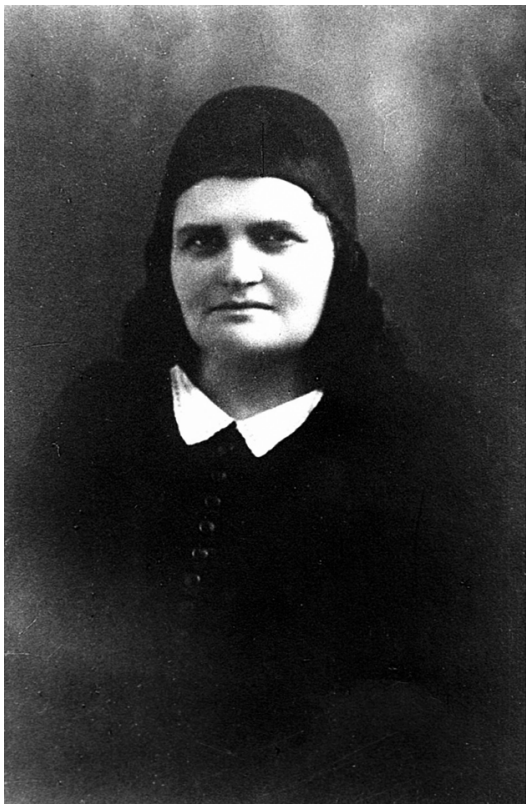

Rachela (Rochl) Fajgenberg (Feigenberg, 1885-1972), pisarka tworząca w językach jidysz i hebrajskim, dziś przeważnie zapomniana, należała do najpopularniejszych żydowskich autorek i publicystek okresu międzywojennego ${ }^{1}$. Urodzona $\mathrm{w}$ rabinackiej rodzinie w Lubaniu w guberni mińskiej (obecnie Białoruś), przed I wojną światową zaczęła publikować opowiadania i nowele w prasie jidysz. W 1919 r. przeżyła falę pogromów

\section{Rachela Fajgenberg}

Źródło: Gnazim Archive of the Hebrew Writers Association in Israel.

${ }^{1}$ Niniejszy tekst został przygotowany na podstawie streszczenia mojego autorstwa zamieszczonego w: Rachela Fajgenberg, Dziewczęce lata. Młodość w poleskim sztetlu, tłum. Inka Stempin, wstęp i oprac. Joanna Nalewajko-Kulikov, Warszawa 2021 (w druku). Dane biograficzne podaję za: Zalmen Rejzen, Leksikon fun der jidiszer literatur, prese un filologie, t. 3, Wilne 1929, kol. 49-56; Leksikon fun der najer jidiszer literatur, t. 7, red. Efroim Ojerbach i in., Nju Jork 1968, kol. 343-346; Mejlech Rawicz, Majn leksikon, t. 1, Montreal 1945, s. 194-196; Rachel Fajgenberg, Ajarati sze-ejnena od, [w:] Pinkas Sluck we-notejha, red. Szimszon Nachmani, Nachum Chonic, Nju Jork-Tel Awiw 1962, s. 201-203; taż, Ha-liubanim le-bejt imi, [w:] tamże, s. 220-223; taż, Bejt Nachum Epstein, [w:] tamże, s. 223-224; Sheva Zucker, Rokhl Faygnberg (1885-1972), Jewish Women's Archive, https:/jwa.org/encyclopedia/article/faygnberg-imri-rokhl [dostęp: 15 października 2020]. 
w okolicach Odessy, po czym aktywnie uczestniczyła w zbieraniu i publikowaniu relacji naocznych świadków o pogromach. W latach dwudziestych XX w. krążyła między Rumunią, Polską, Francją i Palestyną, współpracując stale z warszawskim dziennikiem jidyszowym „Der Moment”; zaangażowała się także w obronę Szaloma Schwarzbarda w trakcie procesu o zabójstwo Symona Petlury. Jej publicystyka dotyczyła znaczenia Palestyny dla Żydów, tożsamości żydowskiej, problemu asymilacji młodego pokolenia oraz - przede wszystkim - tzw. kwestii kobiecej. Od 1933 r. Fajgenberg mieszkała na stałe w Palestynie i publikowała przede wszystkim po hebrajsku pod nazwiskiem Rachel Imri. W 1945 r. założyła w Jerozolimie wydawnictwo Ha-Measef, którego celem miało być wydanie po hebrajsku najważniejszych utworów literatury jidysz; niestety, z braku zainteresowania oraz środków finansowych upadło ono po wydaniu trzech książek. Sama Fajgenberg nigdy nie osiągnęła w Izraelu takiej pozycji, jaką cieszyła się w diasporze, choć publikowała nadal sporo; wydała m.in. pięciotomową serię Megilot Jehudej Rusja: 1905-1964 [Kroniki Żydów Rosji: 1905-1964, Jerozolima 1965].

Autobiografia pt. Di kinder-jorn [Dziecięce lata], opublikowana w odcinkach w 1905 r. na łamach petersburskiego miesięcznika „Dos Leben”, a w formie książkowej w 1909 r. w Warszawie, to literacki debiut Fajgenberg, który zwrócił uwagę krytyków i czytelników. Autorka opisuje w nim swoją rodzinę ze strony matki i ojca, życie codzienne sztetla upływające w rytmie pór roku i świąt religijnych oraz własny proces dorastania. Jej opowieść uderza bogactwem szczegółów etnograficznych, dotyczących przede wszystkim kobiecej przestrzeni domu i sztetla. Podczas gdy młodszy brat autorki uczy się w chederze, ona musi pomagać matce $\mathrm{w}$ prowadzeniu sklepu, od czego ucieka w sferę marzeń i literatury pięknej - doświadczenia czytelnicze z bardzo popularnymi powieściami Szomera (właśc. Nochema Mejera Szajkiewicza, 1849?-1905) stanowią jeden z ważniejszych wątków książki. Innym ważnym wątkiem jest relacja z matką, a także jej choroba i śmierć. Opowieść kończy się, gdy po śmierci matki 14-15-letnia narratorka wyjeżdża do Odessy, oddana pod opiekę babci. Jakkolwiek Fajgenberg zmieniła w autobiografii niektóre szczegóły (nazwy miejscowości $^{2}$ czy imiona opisywanych osób) umożliwiające identyfikację, nie ulega wątpliwości, że tekst ten oddaje jej osobiste doświadczenia. grafii.

${ }^{2}$ Na przykład Słuck występuje jako Selc - zob. zamieszczony dalej fragment autobio- 
W drukowanym poniżej fragmencie autobiografii Fajgenberg opisuje stosunkowo krótki okres swojego życia, kiedy odbierała podstawy edukacji w zakresie nauki hebrajskiego, pisania oraz czytania Tanachu, i podkreśla wagę, jaką do jej edukacji przywiązywała jej matka oraz ona sama. Wspomina także własne zamiłowanie do czytania w szabes budujących historii, składających się na literaturę religijną w jidysz przeznaczoną dla Żydówek. Ten fragment wspomnień dobrze pokazuje pozycję samej autorki w stosunku do opisywanych zjawisk - jako narratorki będącej zarazem dzieckiem swojego środowiska i swojej epoki, a jednocześnie mającej stale poczucie inności i lekkiej wyższości wobec koleżanek z racji odmiennych zainteresowań, ambicji i marzeń.

Joanna Nalewajko-Kulikov

Polska Akademia Nauk email: jnalewajko@ihpan.edu.pl 


\section{Rachela Fajgenberg Dziewczęce lata. Młodość w poleskim sztetlu (fragment) ${ }^{3}$}

Mama bardzo dbała o nasze wychowanie. Mojego braciszka oddała na naukę do najlepszego mełameda w sztetlu. Na to nie skąpiła pieniędzy. Był to zdolny chłopak, co dostrzeżono już, gdy miał zaledwie trzy lata i uczono go odmawiać kadisz zaraz po śmierci ojca. Wystarczyło, że powtórzył dwa razy i już umiał. Kadisz odmawiał tak, że wszyscy zgromadzeni w szulu mężczyźni nie mogli wyjść z podziwu, a kobiety zalewały się łzami, patrząc na niego.

Mnie mama oddała na naukę do Michała Mełameda [Michał der Melamed], który wynajmował u nas pokój za siedem rubli czynszu rocznie. Mama płaciła mu za naukę dziesięć złotych za semestr. Uczył mnie zwykle, kiedy wracał $\mathrm{z}$ chederu - około ósmej wieczorem.

Mój mełamed Michał był wysokim, szczupłym mężczyzną z długą, czarną brodą. Twarz miał bladą, ponieważ mięso jadał tylko w szabes. Na więcej nie mógł sobie pozwolić. Był człowiekiem uczciwym i nikomu w życiu nie był dłużny nawet kopiejki. Jeśli ktoś mu kiedyś coś pożyczył, nie musiał o tym pamiętać, ponieważ wiadomo było, że Michał pamięta o swoich długach. Sama kiedyś widziałam, jak zatrzymał na ulicy jakiegoś goja, by oddać mu grosz, który był mu winien. Goj zaśmiał mu się prosto w twarz i powiedział, że pierwszy raz w życiu widzi tak głupiego człowieka. [...]

Moim drugim nauczycielem był Nechemiasz Pisarz [Nechemia der Szrajber]. Był to młody człowiek, maskil, który przyniósł z Mińska do naszego sztetla miłość do Syjonu. Nechemiasz potrafił pisać, a także trochę mówić po rosyjsku. Po każdym słowie dodawał zawsze $d a$ i dlatego w naszym sztetlu wołano na niego „Rusek”4. [...]

Nechemiasz był nauczycielem pisma dla dziewczą ${ }^{5}$ i nikt się specjalnie jego wyjazdem nie przejął, ponieważ w naszym sztetlu nie było takich matek, które by chciały, żeby ich córki potrafiły pisać. „A czy ja wiem, na

3 Tom wspomnień Racheli Fajgenberg, z którego pochodzi niniejszy fragment, w oryginale zatytułowany Di kinder-jorn [Dziecięce lata] (Warszawa 1909), ukaże się w serii „Żydzi. Polska. Autobiografia” pod tytułem Dziewczęce lata. Młodość w poleskim sztetlu w tłumaczeniu z jidysz Inki Stempin i opracowaniu Joanny Nalewajko-Kulikov.

4 W oryginale: der Rusak.

${ }^{5}$ Większość chederów w Europie Wschodniej ograniczała się tylko do nauczenia umiejętności czytania. Umiejętności pisania w jidysz lub po rosyjsku uczyli pisarze (jid. szrajbers), przychodzący do domów uczniów po szkole. 
co przyda się dziewczynie pisanie? Będzie zapisywała, ile kaszy wsypie do garnka?" - mawiały.

Wyjątkiem były dwie bogaczki, które pragnęły, by ich córki nauczyły się pisać. Jedną była Gołda Lea, żona Arona Rochesa, największa bogaczka w naszym sztetlu, która wychowała się w dużym mieście Rabińskư $\mathrm{i}$ potrafiła trochę pisać oraz rachować. Jej mąż handlował drewnem, a ona sama prowadziła sklep tekstylny, w którym towaru było za trzysta rubli, a może nawet więcej. Drugą bogaczką, która chciała dać lepsze wykształcenie swojej córce, była moja matka, bogata wdowa z naszego sztetla. Chciała ona, by jej córka umiała pisać nie tylko w jidysz, ale nawet po hebrajsku i rosyjsku. Rosyjskiego mama nie lubiła i mawiała, że wystarczy, jeśli dziewczyna będzie potrafiła zapisać adres - więcej nie potrzeba. Za to bardzo ceniła loszn kojdesz ${ }^{7}$ i zwykła ciągle wyobrażać sobie, jaka będzie szczęśliwa, kiedy jej jedyna córka dzięki znajomości świętego języka osiągnie wysoką pozycję. [...] W czasach swej młodości mama nosiła się z myślą, że kiedyś wyrwie się z mroków niewiedzy i będzie wiodła bardziej światłe życie, kiedy jednak okazało się, że nie było jej to przeznaczone, przeniosła swoje nadzieje z młodości na dzieci i przez nie chciała uzyskać to, czego jej samej nie udało się osiągnąć. W swej pobożności wierzyła, że za wszystkie cierpienia, których w życiu doznała, Bóg obdarzy ją dobrymi dziećmi. I tak też już to trochę widziała - jej syn był najlepszym uczniem w chederze, a dziewczynka, jak twierdził Michał, też była zdolna. „Szkoda tylko, że jest dziewczynką” - dodawał. „Gdyby była chłopcem, wyrósłby z niej na pewno wielki rabin".

Mama postanowiła więc, że będę uczyć się hebrajskiego i wkrótce oddała mnie na naukę Tanachu do Oriego Mełameda [Ori der Melamed]. Miałam więc dwóch nauczycieli naraz: Oriego od Tanachu i Nechemiasza od jidysz i rosyjskiego. Nechemiasz uczył mnie w ciągu dnia, a Ori o ósmej wieczorem $[\ldots]$

W sobotę po kolacji chodziłam do niego do domu. Mieszkał daleko od nas, aż na ulicy Cygańskiej, gdzie miał niewielką izbę z trzema małymi okienkami. Nie wszystkie szyby w oknach były całe - niektóre były zabite szczapami, niektóre zatkane szmatami i dlatego w izbie panował półmrok.

${ }^{6}$ Chodzi o Bobrujsk, miasto powiatowe w guberni mińskiej, w 1880 r. liczące 37237 mieszkańców, w tym 17935 Żydów, którzy zajmowali się głównie handlem - zob. Słownik geograficzny Królestwa Polskiego i innych krajów stowiańskich, red. Filip Sulimierski, Bronisław Chlebowski, Władysław Walewski, t. 1, Warszawa 1880, s. 266.

${ }^{7}$ Loszn kojdesz (z hebr. laszon kodesz ‘język święty’) - powszechne określenie hebrajskiego z elementami aramejskiego, czyli języka liturgii i studiów religijnych. 
Miejsca było mało, gdyż połowę przestrzeni zajmował bardzo duży piec. W drugiej połowie izby znajdowały się długie, białe ławy, biały stół, dwa łóżka pełne pościeli i wisząca na sznurach kołyska. Ściany poczerniały od dymu unoszącego się z małej, naftowej lampki. Podłoga pozostawała zawsze wilgotna, ponieważ było to tylko klepisko, a do tego jeszcze wylewano na nie pomyje. Kiedy przychodziłam tam w sobotę, zastawałam ich jeszcze przy kolacji. Jadali na brudnym obrusie, z podrutowanych talerzy i posklejanej miski. Łyżki były różne: dwie, trzy blaszane, a pozostałe drewniane.

Żona i dzieci Oriego dobrze pasowały do jego zaniedbanego gospodarstwa. Żona była masywna i wysoka, a jej twarz przybierała czasem żółtawy, czasem zielonkawy kolor. Oddychała krótko i z trudem, a do tego ciągle świszczało jej w płucach, zwłaszcza gdy siedziała w swojej zadymionej izbie z wilgotną podłogą.

Tak wyglądało ich życie w zwykłe dni tygodnia, w szabes natomiast izba odżywała - było czysto i sucho, a do tego zjadano dobry obiad i odpoczywano. Gospodarz przebywał w domu i robiło się tu wtedy po prostu jakoś jaśniej niż na co dzień. Jak gdyby sam szabes rozjaśniał oczy i dzięki temu spojrzenie Oriego stawało się bardziej ożywione, a nawet jakby się trochę uśmiechał pod nosem. [...]

Ori i pozostali domownicy czuli się szczęśliwi, siedząc w szabes przy stole, ja jednak nie czułam się tam dobrze. Było mi ich bardzo żal i chciałam jak najszybciej stamtąd uciec, żeby nie patrzeć na ich biedę. Chciałam widzieć wesołe rzeczy i Bóg mi w tym wkrótce dopomógł. Bogacz Aron Roches sprowadził dla swoich dzieci drogiego, ale dobrego nauczyciela. Płacił mu trzydzieści pięć rubli za semestr, zapewniając też wikt oraz opierunek, i zgodził się, bym także ja uczyła się razem z jego dziećmi. Moja mama ledwo dała się uprosić.

Nowy nauczyciel również miał bladą twarz i zapadnięte policzki, nie wyglądał jednak tak okropnie jak Ori. Chodził schludnie ubrany, po części jak nowoczesny Europejczyk. Można było o nim powiedzieć, że był w połowie z nowoczesnego, a w połowie ze starego świata. Cenił oba te światy - był zarówno wykształcony, jak i pobożny. Był maskilem, podobnie jak Nechemiasz Pisarz, jednak lepiej od niego wykształconym i dużo mądrzejszym. Swoją uczciwością przypominał Michała. Zwykł ściśle przestrzegać czasu nauki. „Nie powinno się marnować cudzego czasu” mawiał. Zdawał się zawsze zadowolony ze swego położenia, nigdy nie narzekał i patrzył na życie z uśmiechem. [...] 
Do takiego nauczyciela trafiłam po Orim, którego nie mogłam znieść. Wraz z rozpoczęciem nauki u nowego nauczyciela otworzył się przede mną nowy, piękniejszy, bogatszy i większy świat, pełen nieznanych wcześniej przyjemności i pragnień. Z zadymionej izby Oriego trafiłam do salonu Arona Rochesa, u którego na pomalowanej podłodze stały wytworne meble z czerwonymi, barchanowymi obiciami, a w oknach wisiały tiulowe zasłony - zupełnie jak nie w żydowskim domu, tylko jak u księdza ${ }^{8}$ albo dziedzica. Bardzo mi się to wszystko podobało. Patrzyłam na piękne pokoje i marzyłam, że kiedyś, kiedy wyjdę za mąż i zamieszkam w dużym mieście, też tak urządzę sobie dom z pięknym salonem. Pamiętam, że przez parę pierwszych dni nauki byłam jak zaczarowana. Myślałam tylko o pięknym mieszkaniu z tiulowymi zasłonami. Ucząc się tam, czułam się jak w raju. [...]

Czułam się tam dobrze również dlatego, że miałam przyjaciółkę, która uczyła się razem ze mną. Była to starsza córka bogacza. Byłyśmy obie w tym samym wieku i miałyśmy takie same umiejętności, tylko że ona była szczęśliwsza ode mnie, ponieważ miała ojca, w dodatku bogatego. W domu bardzo ją rozpieszczano i ustępowano jej we wszystkim. Nie musiała nigdy niczego robić, ponieważ u nich wszystkim zajmowała się służba. Chodziła zawsze pięknie ubrana i jadła tylko najlepsze potrawy. W środku tygodnia spacerowała w odświętnych ubraniach tak jak panienki - córki księdza. Zazdrościłam jej bardzo, ponieważ moje życie było zupełnie inne. Musiałam ciągle harować jak wół - w domu wszystko robiłam sama, a w sklepie pilnowałam towarów i kiedy jakiś goj coś ukradł, mama spuszczała mi lanie za to, że nie uważam i że w głowie mi tylko zabawy z dziewczętami. „Już czas wyrzucić z głowy te głupstwa!” - mówiła. „Nie jesteś już małym dzieckiem tylko jedenastoletnią dziewczyną! Chcesz być jak Merka, córka Arona? Do niej nie masz się co porównywać!” [...]

Bardzo mnie martwiło, że nie miałam czasu na powtarzanie tego, czego się uczyliśmy. Zawsze musiałam coś robić w domu albo w sklepie i na naukę miałam tylko trzy godziny dziennie - kiedy uczyłam się z nauczycielem. $\mathrm{Na}$ odrabianie lekcji nie zostawało mi już czasu. Ciągle jednak o nich myślałam. Gdy zamiatałam mieszkanie, obierałam kartofle czy odważałam funt mąki - myśli w mojej głowie krążyły wokół tego, czego nauczyłam się poprzedniego dnia. [...]

Moja matka była bardzo dobra i czuła, ale nas nie rozpieszczała. Za najdrobniejsze przewinienia karała surowo. Najczęściej obrywało mi się od

${ }^{8}$ W niniejszym tekście „ksiądz” oznacza wyłącznie duchownego prawosławnego. 
niej za kradzieże, które przydarzały się w sklepie. Goje z naszego sztetla byli wielkimi złodziejami. Wszystko stanowiło dla nich łakomy kąsek, nawet bajgiel. Za każdą nieupilnowaną rzecz, którą ukradli, dostawałam od mamy lanie i razy te wywoływały we mnie wrogość do gojów. Na każdego goja patrzyłam jak na złodzieja i rozbójnika. Nie potrafiłam sobie w ogóle wyobrazić, by wśród gojów też mogli być przyzwoici ludzie. Wtedy jeszcze nie wiedziałam, że wszystkie występki, które zarzucałam gojom, były takie same, jak oskarżenia, które goje kierowali przeciwko Żydom. Dla gojów wyglądało to dokładnie odwrotnie - to Żydzi są złodziejami wysysającymi krew z chrześcijańskich narodów. [...]

Dzień szabesu dawał mi siły na cały tydzień. $\mathrm{O}$, jak drogi był dla mnie ten święty dzień! W nim znajdowałam wszystko to, czego brakowało mi w tygodniu - odpoczynek, sen, dobre jedzenie, spacery z moją bogatą przyjaciółką, a zwłaszcza przyjemność czytania. Czytanie było dla mnie całym światem. Czytając Szewet musar ${ }^{9}$ oraz Kaw ha-jaszar ${ }^{10}$, czułam się szczęśliwa. Myślałam, że na całym świecie nie ma nic lepszego do czytania. Bardzo drogie były mi także parsze $\mathrm{z}$ ich pięknymi historiami o naszym dawnym życiu, a Szewet musar przyciągała mnie swoimi strasznymi opowieściami o Gehennie.

W Szewet musar czytałam, że już na samych drzwiach do Gehenny można zobaczyć straszne rzeczy zapowiadające to, co dzieje się wewnątrz, a mianowicie ludzi powieszonych za stopy, ręce lub włosy. Za włosy wieszano kobiety, ukarane w ten straszny sposób z powodu niezakrywania swoich włosów ${ }^{11}$. Czytając o tym, myślałam, jak bardzo nieszczęśliwi byli ludzie, którzy tam wpadali. Cała moja pobożność brała się ze strachu przed Gehenną, ponieważ bałam się każdego rodzaju kary. Myślałam sobie wtedy, że im będę starsza, tym będę pobożniejsza, a już z pewnością pobożna stanę się, kiedy wyjdę za mąż. Zamierzałam wypełniać wszystkie

${ }^{9}$ Szewet musar (hebr. 'rózga napomnienia') - dzieło autorstwa Elijahu ha-Kohena ha-Itamriego, należące do nurtu literatury pobożnościowej, składające się z 52 rozdziałów odpowiadających kolejnym tygodniom roku. Wydane po raz pierwszy w 1712 r. w Konstantynopolu, zyskało dużą popularność w przekładzie na jidysz.

${ }^{10}$ Kaw ha-jaszar (hebr. 'sprawiedliwa miara') - dzieło kabalisty Cwiego Hirsza Kojdanowera; klasyczny przykład literatury kabalistycznej z początku XVIII w., traktującej głównie o działalności demonów oraz metodach walki z nimi. Praca ta, przełożona na jidysz przez autora, cieszyła się wśród kobiet dużą popularnością.

${ }^{11}$ Chodzi o religijny nakaz zakrywania włosów przez kobiety, zwłaszcza kobiety zamężne. Do końca XVIII w. noszono w tym celu czepki, chusty i tym podobne nakrycia głowy, jednak wobec zakazu ich używania przez władze carskie (w ramach walki z tradycyjnym strojem żydowskim) w XIX w. upowszechniły się peruki, często wykonywane z własnych włosów. 
micwy, modlić się trzy razy dziennie, nie jeść, nie odmówiwszy wcześniej błogosławieństwa, i gdy tylko będę mogła - odmawiać sto błogosławieństw dziennie. Myślałam sobie, że wtedy już na pewno zostanę pobłogosławiona! Planowałam też pięknie obchodzić szabes i wszystkie święta, a jeśli będę bogata $-z$ wielką pompą darowywać zwoje Tory do synagog. Moją ulubioną micwą była micwa jałmużny, którą uważałam za dobrą i prostą. Micwa modlenia się natomiast przychodziła mi z trudem. Zawsze, zanim zaczęłam się modlić, rozgrywała się w moim sercu prawdziwa wojna. Walczyły ze sobą jecer tow i jecer hore ${ }^{12}$, micwa modlenia się z pasją czytania książek. [...]

Nie mając dostępu do wielkich powieści, zadowalałam się krótkimi opowiadaniami. W każdym znajdowałam coś szczególnie interesującego i wszystkie je pamiętałam. W szabes gromadziłam wokół siebie kilkadziesiąt dziewcząt i opowiadałam im różne historyjki. Czasami snułam też opowieści przed starszymi ludźmi; były to już jednak całkiem inne historie. Siadywałam wtedy w szabes pośród kobiet na ganku u ciotki Zlaty i opowiadałam im, co przeczytałam w książkach babci: w Szewet musar, w Kaw ha-jaszar, w Bechinat olam ${ }^{13}$. Zwłaszcza jedna historia bardzo im się podobała i ciągle mnie prosiły, żebym im ją opowiedziała. Była to opowieść z Gur arie ${ }^{14}$. Do dziś jeszcze dobrze ją pamiętam. Wszystkie kobiety zachwycały się tą historią i mówiły, że gdy ją opowiadam, sypią się z moich ust perły, całkiem jak z ust prawdziwego magida. „A tu jak na złość z taką dobrą głową urodziła się dziewczynka" - dodawały.

W sztetlu znana byłam nie tylko z pięknego opowiadania, lecz także z pisania listów. $\mathrm{Z}$ całego sztetla przychodzili do mnie ludzie z prośbą, bym napisała dla nich list. Nikt nie musiał mi tłumaczyć, co mam napisać, ponieważ zawsze wiedziałam, co dana osoba chciała w liście wyrazić. Napisałam nawet dla pewnej dziewczyny list do jej narzeczonego. List ten zrobił prawdziwą furorę. Zaczynał się od słów: „Szlachetnie urodzony, czcigodny narzeczony". Zapomniałam już, co było dalej, pamiętam jednak, że w odpowiedzi narzeczony ów napisał, że jest niezmiernie szczęśliwy, iż jego narzeczona potrafi pisać takie mądre listy, czego wcześniej jakoś nie zauważył. Narzeczona natomiast życzyła mi w zamian, żebym wkrótce miała

${ }^{12}$ Jecer tow (hebr.) - 'popęd skłaniający do czynienia dobra'; jecer hore (jid., z hebr.) 'popęd skłaniający do czynienia zła'. Oba popędy koegzystują w każdym człowieku.

${ }_{13}$ Bechinat olam (hebr. 'badanie świata') - poemat filozoficzny rabina Jedai ben Abrahama Bedersiego, żyjącego na przełomie XIII i XIV w.

${ }^{14}$ Gur arie (hebr. 'młody lew') - komentarz praskiego rabina Jehudy Loewa ben Becalela (zwanego Maharal) do komentarza Rasziego do Tory, wydany po raz pierwszy w Pradze w $1578 \mathrm{r}$. 
sposobność pisać listy do swojego narzeczonego. Stwierdziła, że skoro do obcego piszę tak pięknie, to co dopiero gdy będę pisać do własnego narzeczonego. I ja sama, prawdę powiedziawszy, nie mogłam się tego doczekać. Marzyłam już wtedy trochę o narzeczonym i pisząc do cudzego, wyobrażałam sobie, że to mój własny, i włożyłam w ten list całe serce.

Tak oto upłynęło moje dzieciństwo do dwunastego roku życia. Miałam już za sobą semestr nauki u nowego nauczyciela i zrobiłam duże postępy. Potrafiłam pisać w loszn kojdesz, a także trochę po rosyjsku. Mama powiedziała, że jeśli skończę u niego jeszcze jeden semestr, pośle mnie do Selca ${ }^{15}$ na naukę rosyjskiego do jakiegoś znakomitego rosyjskiego skryby. [...] W głowie stwarzałam już nowy, wielki świat. Wyobrażałam sobie, co zobaczę w wielkim mieście i jak będzie wyglądał mój powrót z Selca do domu - jak wszyscy będą mnie wypytywali o wielkomiejskie życie i zazdrościli mi, że wszystko wiem i że jestem tak wykształcona, że znam rosyjski. I może zajdę w mojej edukacji tak daleko, że będę mogła przeczytać po rosyjsku książkę. Kto wie? Moja wyobraźnia ponosiła mnie coraz dalej: będę potrafiła czytać i mówić po rosyjsku, będę mogła rozmawiać z córkami księdza, a może nawet będę uczęszczać na pensję razem ze wszystkimi bogatymi dziewczętami, chodzić w brązowej szkolnej sukience i codziennie nosić ze sobą do klasy książki. Cała aż drżałam ze szczęścia, gdy o tym wszystkim myślałam. Moje nadzieje były wielkie, choć nie wiedziałam, jak miałoby mnie spotkać to szczęście, by się ziściły. Czekałam na cud, na zrządzenie losu, dzięki któremu wyjedziemy do Selca. [...]

Nieszczęsne dziecko, próżne twe nadzieje! Dość już uczenia się! Przygotuj się lepiej na ważniejsze sprawy niż nauka. Czekają na ciebie inne doświadczenia - będziesz pracować, i to pracować za darmo, a śmierć obmyśla już, jak ponownie wejść do twojego domu.

\section{Z jidysz przełożyła Inka Stempin}

Opracowanie i przypisy Joanna Nalewajko-Kulikov

${ }^{15}$ Chodzi o Słuck, wówczas miasto powiatowe w guberni mińskiej, liczące w 1889 r. ok. 20 tys. mieszkańców, w tym ok. 10-11 tys. Żydów - zob. Słownik geograficzny Królestwa Polskiego i innych krajów słowiańskich, red. Bronisław Chlebowski, Władysław Walewski, t. 10, Warszawa 1889, s. 838. 